\title{
OBSERVATIONS ON THE ETIOLOGIC RELATIONSHIP OF ACHYLIA GASTRICA TO PERNICIOUS ANEMIA. VIII. FURTHER STUDIES OF THE PROTEOLYTIC ACTIVITY OF NORMAL HUMAN GASTRIC JUICE IN VITRO; AND THE LIMITATIONS OF THE METHOD IN PERNICIOUS ANEMIA ${ }^{1}$
}

\author{
By C. J. GESSLER, ${ }^{2}$ S. O. DEXTER, MARGARET A. ADAMS AND F. H. L. TAYLOR \\ (From the Thorndike Memorial Laboratory, Second and Fourth Medical Services (Harvard), \\ Boston City Hospital, and the Department of Medicine, Harvard Medical School, Boston)
}

(Received for publication September 6, 1939)

It has been shown in previous studies $(1,2)$ that normal human gastric juice contains a proteolytic enzyme capable of hydrolyzing casein to the proteose stage in an alkaline medium, but not at hydrion concentrations below $\mathrm{pH}$ 4. This range of activity and certain other properties would seem to distinguish the enzyme from pepsin, while the failure of the enzyme to produce large amounts of amino-nitrogen within 24 hours appears to rule out trypsin and erepsin, acting in their generally accepted manner.

Although no assertion can be made that this proteolytic activity is identical with that of the so-called intrinsic factor as detected clinically, it is of interest that the proteolytic activity in question is retained or destroyed under certain circumstances which affect the clinical activity of the intrinsic factor in a similar fashion (2). The present communication presents further resemblances of this nature. It also includes data indicating the limitations of the method of the in vitro hydrolysis of casein as a means of determining the activity in question in samples of the gastric contents of patients with pernicious anemia.

\section{A. Effect of adsorption with Lloyd's reagent and of dialysis upon normal human gastric juice}

Gastric juice visibly free from bile was collected from normal persons after the administration of $0.5 \mathrm{mgm}$. of histamine phosphate. This fresh gastric juice or subsequent modifications were brought to approximately $\mathrm{pH} 7.4$ with normal sodium hydroxide. Fifty $\mathrm{ml}$. of such ma-

1 The expenses of this investigation were defrayed in part by the J. K. Lilly Gift to the Harvard Medical School.

2 Graduate Fellow of the Belgian-American Educational Foundation, 1937-1939. terials were rapidly mixed in an Erlenmeyer flask with $50 \mathrm{ml}$. of a 1 per cent neutral casein solution prepared as previously described (2). The mixture was adjusted to exactly $\mathrm{pH} 7.4$ and $2 \mathrm{ml}$. of toluol were added. The flasks were then set in a constant temperature bath at $37.5^{\circ} \mathrm{C}$. for 24 hours. Samples of the digestion mixture were removed immediately and after 24 hours, and analyzed for the total amount of nitrogen not precipitable by 10 per cent trichloracetic acid and for the amino-nitrogen content, respectively. From these determinations the amount of total filtrable nitrogen and of amino-nitrogen produced in 24 hours was calculated.

1. Adsorption of normal human gastric juice with Lloyd's reagent. Helmer and Fouts (3) have shown that after normal human gastric juice is shaken with from 10 to 15 grams of Lloyd's reagent, its hematopoietic power in pernicious anemia, when fed daily with 4.5 grams of powdered Liver Extract Lilly (N. N. R.) as a source of extrinsic factor, is reduced by one-half to twothirds. In our (2) hands, however, after this procedure the gastric juice retained in vitro no detectable proteolytic activity. It was suggested that the residual activity of the gastric juice found by Helmer and Fouts might have been due to a greater content of mucus, which might have interfered with the adsorptive power of the Lloyd's reagent. Since the adsorption by Lloyd's reagent seemed to offer a reasonable method of concentration of the enzyme, it was decided to repeat both the in vitro and the clinical observations.

Accordingly, samples of $100 \mathrm{ml}$. of unneutralized normal human gastric juice were filtered through gauze, then shaken once with 10 grams of Lloyd's reagent and filtered or centrifuged free of the adsorbent. In certain instances the acid 
gastric juice was neutralized before adsorption or was treated twice with 15 grams of Lloyd's reagent. In one experiment 6.5 grams of commercial mucin were added to $100 \mathrm{ml}$. of gastric juice before adsorption with Lloyd's reagent. The variations as well as the results of the different experimental techniques are given in Table I. The data given there show that, while untreated gastric juice produced marked increases in total filtrable nitrogen, those samples adsorbed either once or twice with Lloyd's reagent were found to be inert in this respect, regardless of the reaction of the gastric juice at the time the adsorption was carried out. The results of experiments $93 \mathrm{a}$ and $93 \mathrm{~b}$ indicate that the addition of mucin to the gastric juice permitted retention of about 25 per cent of the original proteolytic power when extracted only once with Lloyd's reagent, as Helmer and Fouts had done.

A clinical test of gastric juice which had been

TABLE I

Proteolytic activity of normal human gastric juice on casein at pH 7.4 after adsorption with Lloyd's reagent

\begin{tabular}{|c|c|c|c|c|c|}
\hline \multirow{2}{*}{$\begin{array}{c}\text { Experi- } \\
\text { mumber } \\
\text { number }\end{array}$} & \multicolumn{3}{|c|}{$\begin{array}{l}\text { Conditions during adsorption } \\
\text { of } 100 \mathrm{ml} \text {. of gastric juice } \\
\text { with Lloyd's reagent }\end{array}$} & \multicolumn{2}{|c|}{$\begin{array}{l}\text { Subsequent proteolytic } \\
\text { activity }\end{array}$} \\
\hline & $\begin{array}{l}\text { Lloyd's } \\
\text { reagent }\end{array}$ & $\begin{array}{c}\text { Number } \\
\text { of ad- } \\
\text { sorptions }\end{array}$ & $\begin{array}{l}\text { pH dur- } \\
\text { ing ad- } \\
\text { sorption }\end{array}$ & $\begin{array}{l}\text { Increase in } \\
\text { nitrogen in } \\
\text { trichlor- } \\
\text { acetic acid } \\
\text { filtrates }\end{array}$ & $\begin{array}{l}\text { Increase in } \\
\text { amino-nitro- } \\
\text { gen by for- } \\
\text { mol titration }\end{array}$ \\
\hline & grams & & & \multicolumn{2}{|c|}{$\begin{array}{l}\text { mgm. per } 100 \text { ml. digest } \\
\text { in } 24 \text { hours }\end{array}$} \\
\hline $\begin{array}{l}65 a \\
65 b\end{array}$ & $\begin{array}{r}0 \\
10\end{array}$ & $\begin{array}{l}0 \\
1\end{array}$ & 7.4 & $\begin{array}{r}53.92 \\
0.34\end{array}$ & $\begin{array}{l}1.82 \\
0.00\end{array}$ \\
\hline $\begin{array}{l}67 \mathrm{a} \\
67 \mathrm{~b}\end{array}$ & $\begin{array}{r}0 \\
10\end{array}$ & $\begin{array}{l}0 \\
1\end{array}$ & $\begin{array}{l}0 \\
1.8\end{array}$ & $\begin{array}{r}15.50 \\
0.00\end{array}$ & $\begin{array}{l}0.00 \\
0.00\end{array}$ \\
\hline $\begin{array}{l}68 \mathrm{a} \\
68 \mathrm{~b}\end{array}$ & $\begin{array}{r}0 \\
10\end{array}$ & $\begin{array}{l}0 \\
1\end{array}$ & 7.4 & $\begin{array}{r}47.20 \\
0.24\end{array}$ & $\begin{array}{l}0.30 \\
0.50\end{array}$ \\
\hline $\begin{array}{l}70 \mathrm{a} \\
70 \mathrm{~b} \\
70 \mathrm{c}\end{array}$ & $\begin{array}{r}0 \\
10 \\
10\end{array}$ & $\begin{array}{l}0 \\
1 \\
1\end{array}$ & $\begin{array}{l}7.4 \\
1.2\end{array}$ & $\begin{array}{r}12.29 \\
1.14 \\
0.00\end{array}$ & $\begin{array}{l}0.70 \\
0.00 \\
0.00\end{array}$ \\
\hline $\begin{array}{l}93 \mathrm{a}^{*} \\
93 \mathrm{~b}^{*}\end{array}$ & $\begin{array}{r}0 \\
10\end{array}$ & $\begin{array}{l}0 \\
2\end{array}$ & 1.2 & $\begin{array}{r}23.00 \\
5.20\end{array}$ & $\begin{array}{l}1.38 \\
0.00\end{array}$ \\
\hline $\begin{array}{l}133 \mathrm{a} \\
133 \mathrm{~b}\end{array}$ & $\begin{array}{r}0 \\
10\end{array}$ & $\begin{array}{l}0 \\
2\end{array}$ & 1.8 & $\begin{array}{r}40.30 \\
0.48\end{array}$ & $\begin{array}{l}1.40 \\
0.00\end{array}$ \\
\hline $\begin{array}{l}275 a \\
275 b\end{array}$ & $\begin{array}{r}0 \\
15\end{array}$ & $\begin{array}{l}0 \\
2\end{array}$ & 1.8 & $\begin{array}{r}22.97 \\
0.00\end{array}$ & $\begin{array}{l}0.28 \\
0.00\end{array}$ \\
\hline
\end{tabular}

* 6.5 grams of mucin per $100 \mathrm{ml}$. of gastric juice were added in this experiment. Both control and the portion of the sample adsorbed with Lloyd's reagent were exposed to $\mathrm{pH} 10$ for 2 hours before incubation at $\mathrm{pH} 7.4$ for 24 hours.
TABLE II

Effect of daily administration to patients with pernicious anemia of 200 grams of beef muscle with $100 \mathrm{ml}$. of normal human gastric juice after extraction with Lloyd's reagent and after dialysis, respectively

First periods: Daily administration of preparations indicated below

\begin{tabular}{c|c|c|c|c}
\hline & \multicolumn{2}{|c|}{ Case 79 } & \multicolumn{2}{|c}{ Case 80 } \\
\cline { 2 - 5 } $\begin{array}{c}\text { Days of } \\
\text { treatment }\end{array}$ & $\begin{array}{c}100 \text { ml. of gastric juice } \\
\text { after extraction twice with } \\
15 \text { grams of Lloyd's reagent }\end{array}$ & $\begin{array}{c}\text { 100 ml. of gastric juice } \\
\text { after dialysis for } 3 \text { days } \\
\text { at } 4^{\circ} \mathrm{C} .\end{array}$ \\
\cline { 2 - 5 } & $\begin{array}{c}\text { Red blood } \\
\text { cells }\end{array}$ & $\begin{array}{c}\text { Reticulo- } \\
\text { cytes }\end{array}$ & $\begin{array}{c}\text { Red blood } \\
\text { cells }\end{array}$ & $\begin{array}{c}\text { Reticulo- } \\
\text { cytes }\end{array}$ \\
\cline { 2 - 5 } & $\begin{array}{c}\text { millions per } \\
\text { c. mm. }\end{array}$ & per cent & $\begin{array}{c}\text { millions per } \\
\text { c. mm. }\end{array}$ & per cent \\
0 & 1.59 & 1.2 & 1.50 & 1.2 \\
2 & 1.53 & 1.0 & 1.39 & 3.0 \\
4 & 1.59 & 1.2 & 1.40 & 3.5 \\
6 & 1.55 & 2.2 & 1.59 & 5.8 \\
8 & 1.41 & 4.0 & 1.84 & 15.8 \\
10 & 1.46 & 5.6 & 1.94 & 6.4 \\
12 & 1.27 & 5.0 & 2.00 & 5.8 \\
\hline
\end{tabular}

Second periods: Daily administration of preparations indicated below

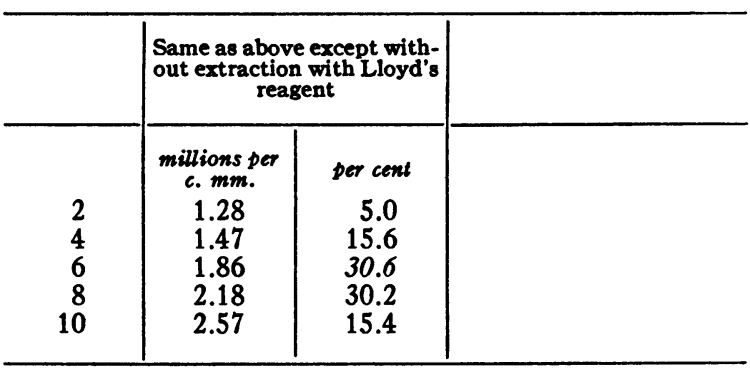

extracted twice with 15 grams of Lloyd's reagent was then carried out. In accordance with a technique previously demonstrated (4) to be effective in the detection of intrinsic factor, a patient with pernicious anemia (Table II, Case 79) was fed 100 grams of finely divided beef muscle and $50 \mathrm{ml}$. of neutralized gastric juice, after extraction with Lloyd's reagent, at both the noon and evening meals each day for a period of 12 days. During this time there was no clinical improvement or laboratory evidence of significantly increased blood formation. During a second period of 10 days the conditions were identical except that freshly neutralized gastric juice was substituted for gastric juice which had been extracted with Lloyd's reagent. The patient then responded clinically and a reticulocyte peak of 30.6 per cent was attained on the sixth day with an 
increase within 10 days of over a million cells above the initial count of $1,270,000$ red blood cells per cu.mm. From this it appears that in vitro evidence of proteolysis, as well as clinical evidence of intrinsic factor activity, was absent after treatment of normal human gastric juice with Lloyd's reagent in the manner described.

2. Dialysis of normal human gastric juice. It has been shown by Helmer and Fouts (3) and by Helmer, Fouts and Zerfas (5) that the intrinsic factor of normal human gastric juice does not pass through an ultrafilter. Goldhamer and Kyer (6) have more recently shown that the precipitate formed by saturation of gastric juice with ammonium sulfate and thereafter dialyzed for 8 hours is potent as a source of intrinsic factor when fed with a suitable extrinsic factor to patients with pernicious anemia.

In order to avoid possible changes in the diffusibility of the intrinsic factor and the introduction of extrinsic nitrogen, preliminary precipitation with ammonium sulfate was omitted, and unprecipitated normal human gastric juice was dialyzed in cellophane sacks at a temperature below $6^{\circ} \mathrm{C}$. for 3 or 5 days, respectively. As dialysis proceeded a white precipitate, presumably the euglobulin of the gastric juice, appeared. The contents of the sack were removed at the end of this period, adjusted if necessary to the original volume with distilled water, and thoroughly mixed. The material was then neutralized and a $50 \mathrm{ml}$. sample was incubated with an equal volume of casein solution at $\mathrm{pH} 7.4$ in the usual manner. The results are given in Table III, experiment 178b. There it will be observed that the dialyzed gastric juice produced significant amounts of total filtrable nitrogen in a manner comparable to that of unmodified gastric juice. In experiment $179 \mathrm{~b}$ the experiment was repeated except that the contents of the sack were filtered through paper before mixing with the casein solution. In experiment $180 \mathrm{a}$ the precipitate left on the paper was resuspended in a volume of distilled water equal to that of the sample before filtration, and incubated with an equal quantity of casein solution. Both the filtrate and the precipitate possessed distinct proteolytic power.

In order to provide a clinical test for intrinsic factor, a patient with pernicious anemia (Table II, Case 80 ) was fed daily $100 \mathrm{ml}$. of dialyzed
TABLE III

Proteolytic activity of normal human gastric juice on casein at $\mathrm{pH} 7.4$ after dialysis

\begin{tabular}{|c|c|c|c|}
\hline $\begin{array}{c}\text { Experi- } \\
\text { ment } \\
\text { num- } \\
\text { ber }\end{array}$ & Preparation of gastric juice & $\begin{array}{c}\text { Increase in } \\
\text { nitrogen in } \\
\text { trichlor- } \\
\text { acetic acid } \\
\text { filtrates }\end{array}$ & $\begin{array}{c}\text { Increase in } \\
\text { amino- } \\
\text { nitrogen } \\
\text { by formol } \\
\text { titration }\end{array}$ \\
\hline & & \multicolumn{2}{|c|}{$\begin{array}{c}\text { mgm. per } 100 \text { ml. digest } \\
\text { in } 24 \text { hours }\end{array}$} \\
\hline $178 \mathrm{~b}$ & $\begin{array}{l}\text { Contents of sack after dialysis } \\
\text { at } 4^{\circ} \mathrm{C} \text {. for } 5 \text { days }\end{array}$ & 53.04 & 0.56 \\
\hline $179 \mathrm{~b}$ & $\begin{array}{l}\text { Filtrate from contents of sack } \\
\text { after dialysis at } 4^{\circ} \mathrm{C} \text {. for } 3 \\
\text { days }\end{array}$ & 57.63 & 0.56 \\
\hline $180 \mathrm{a}$ & $\begin{array}{l}\text { Precipitate from contents of } \\
\text { sack after dialysis at } 4^{\circ} \mathrm{C} \text {. } \\
\text { for } 3 \text { days }\end{array}$ & 51.51 & 0.42 \\
\hline
\end{tabular}

gastric juice and 200 grams of beef muscle in the same manner as in the previous clinical observation. During a period of 12 days the patient responded clinically, and a reticulocyte peak of 15.8 per cent appeared on the eighth day. The red blood cells initially were $1,500,000$ per cu.mm. and reached $2,000,000$ on the twelfth day. These data entirely confirm the clinical observations of others $(3,5,6)$ that intrinsic factor does not pass through a semipermeable membrane, and exclude the possible complication in interpretation introduced through the use of ammonium sulfate before dialysis by Goldhamer and Kyer (6).

\section{DISCUSSION}

The parallelism between the clinical activity of the so-called intrinsic factor and the proteolytic activity of normal human gastric juice under discussion has been further extended to include a similar action of Lloyd's reagent and of dialysis. Nevertheless, this does not constitute proof of identity or imply, as has been proved to the contrary by Wintrobe (7), that casein is a suitable extrinsic factor from a clinical point of view.

\section{B. The in vitro proteolytic activity of the gastric secretion in pernicious anemia}

Until recently no observations had been made in this laboratory on the in vitro proteolytic activity of gastric juice other than from normal human subjects, with the exception of the two instances previously reported (2) in which gastric juice was obtained from patients with pernicious 
anemia. In those observations, marked increases in amino-nitrogen were obtained in 24 hours with such bile-stained gastric contents. It was then found that, after exposure of the material to $\mathrm{pH}$ 10 for 2 hours in order to diminish tryptic activity, both the total filtrable nitrogen and the aminonitrogen production were greatly decreased. These preliminary observations, together with the experiments reported by Lasch (8), suggested the desirability of further in vitro studies of the gastric secretion of patients with pernicious anemia. The present investigations are thus an attempt to test the validity of the casein hydrolysis method as a means of assaying the activity in question in samples of the gastric contents in pernicious anemia. A secondary consideration would obviously be whether such a method could serve as a diagnostic test for pernicious anemia.

Accordingly, samples of the fasting achlorhydric gastric contents of each of 12 patients with pernicious anemia were obtained after the subcutaneous injection of $0.5 \mathrm{mgm}$. of histamine phosphate. In order to secure the necessary $45 \mathrm{ml}$. of material, continuous suction for from 1 to 6 hours was needed. In different patients, as shown in Table IV, the average rate of aspiration varied from 8 to $78 \mathrm{ml}$. per hour. In all but two instances bile was visibly present in the samples. Thus regurgitation from the intestine must have both contaminated and augmented the apparent gastric secretion.

Portions of the samples obtained were incubated in the usual manner with an equal volume of casein solution at $\mathrm{pH}$ 7.4. In only six instances, including the two in which no bile staining was visible, was the amino-nitrogen production less than $2 \mathrm{mgm}$. in 24 hours, even after previous exposure of the gastric contents to alkali (Table IV, lower half). The gastric contents of the other 6 patients, even after exposure to alkali, produced amounts of amino-nitrogen greater than were developed by any of the samples of pure gastric juice from normal individuals previously reported (Table IV, upper half). Experiments 253a and 277a are typical of the very considerable production of amino-acid when exposure to alkali was not practiced. These particular results resemble those previously obtained (2) with normal human gastric juice which had been purposefully contaminated with duodenal contents. In no in-
TABLE IV

Proteolytic activity on casein at pH 7.4 of gastric contents of patients with pernicious anemia

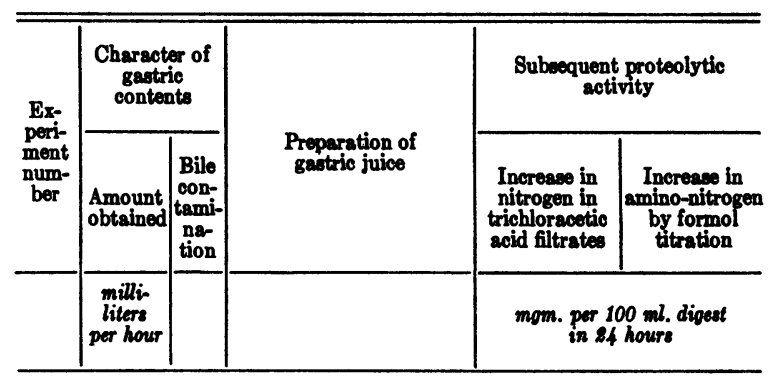

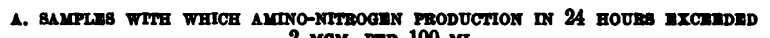
2 MeY. PAR 100 Min.

\begin{tabular}{|c|c|c|c|c|c|}
\hline$\underset{253 \mathrm{~b}}{253 \mathrm{a}}$ & 10 & + & 2 hours exposure to $\mathrm{pH} 10$ & $\begin{array}{l}25.5 \\
17.5\end{array}$ & $\begin{array}{r}25.2 \\
2.4\end{array}$ \\
\hline $\begin{array}{l}92 \mathrm{a} \\
92 \mathrm{~b}\end{array}$ & & + & $\begin{array}{c}\text { None } \\
2 \text { hours exposure to } \mathrm{pH} 10\end{array}$ & $\begin{array}{l}49.8 \\
38.9\end{array}$ & $\begin{array}{r}12.0 \\
6.0\end{array}$ \\
\hline 241 & 8 & + & 2 hours exposure to $\mathrm{pH} 10$ & 50.1 & 4.5 \\
\hline 410 & 20 & + & 2 hours exposure to $\mathrm{pH} 10$ & 54.6 & 6.02 \\
\hline 411 & 38 & + & 2 hours exposure to $\mathrm{pH} 10$ & 75.2 & 8.4 \\
\hline 412 & 37 & + & 2 hours exposure to $\mathrm{pH} 10$ & 80.6 & 2.1 \\
\hline
\end{tabular}

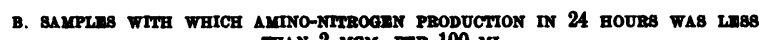
THAN 2 MOM. PAB 100 ax.

\begin{tabular}{|c|c|c|c|c|c|}
\hline $\begin{array}{l}277 \mathrm{a} \\
277 \mathrm{~b}\end{array}$ & 10 & + & $\begin{array}{c}\text { None } \\
2 \text { hours exposure to } \mathrm{pH} 10\end{array}$ & $\begin{array}{l}85.6 \\
21.6\end{array}$ & $\begin{array}{c}15.82 \\
1.7\end{array}$ \\
\hline 414 & 10 & + & 2 hours exposure to $\mathrm{pH} 10$ & 28.7 & 1.4 \\
\hline 407 & 25 & + & 2 hours exposure to $\mathrm{pH} 10$ & 42.4 & 0.8 \\
\hline 245 & 12 & + & 2 hours exposure to $\mathrm{pH} 10$ & 50.1 & 1.82 \\
\hline 408 & 45 & 0 & 2 hours exposire to $\mathrm{pH} 10$ & 19.8 & 0.8 \\
\hline $\begin{array}{l}415 \mathrm{a} \\
415 \mathrm{~b}\end{array}$ & 78 & 0 & $\begin{array}{c}\text { None } \\
2 \text { hours exposure to } \mathrm{pH} 10\end{array}$ & $\begin{array}{l}61.6 \\
63.8\end{array}$ & $\begin{array}{c}10.08 \\
1.4\end{array}$ \\
\hline
\end{tabular}

stance, even after exposure to alkali, was the production of total filtrable nitrogen by samples of the gastric contents of pernicious anemia patients distinctly less than certain values previously reported for normal gastric juice.

Since, according to Northrop (9), only 70 to 80 per cent of trypsin in solution is destroyed by exposure to alkali, the influence of any considerable amount of enzymes regurgitated from the duodenum would remain a seriously interfering factor, even after such a significant reduction by exposure to alkali. This supposition was confirmed by exposure to alkali of solutions containing equal parts by weight of commercial trypsin ${ }^{3}$

8 Trypsin, Pfanstiehl 1:75, Pfanstiehl Chemical Company, Waukegan, Illinois. 
and erepsin 4 in a total concentration of one part per thousand. It was found to be possible to reduce subsequent amino-nitrogen production on casein at $\mathrm{pH} 7.4$ in 24 hours from 12.04 and 10.08 to 0.56 and $2.24 \mathrm{mgm}$., respectively, in two experiments. Yet even after these significant reductions in the formation of amino-nitrogen, the productions of total filtrable nitrogen were, respectively, 22.57 and $79.08 \mathrm{mgm}$. in 24 hours. It was therefore obvious that, when trypsin and erepsin are present in significant amounts in gastric contents, they cannot be sufficiently inhibited by exposure to alkali to render the use of the casein hydrolysis method adequate for the studies of the enzyme under discussion.

\section{DISCUSSION}

In contrast to its apparently successful use in the study of the enzyme activity of normal human gastric juice, the systematic application of the casein hydrolysis technique to the gastric juice of patients with pernicious anemia appears to be impracticable. In the first place, the very slow rate of actual gastric secretion in pernicious anemia permits an unusual degree of contamination with mucus, saliva or intestinal contents. Therefore, on the basis of this dilution effect alone, the secretion obtained can scarcely be considered to represent a sample of gastric secretion in any quantitative sense comparable to that obtained from a normal stomach. In the second place, it is only on rare occasions that adequate samples of gastric contents can be obtained from such patients free from regurgitated intestinal enzymes. Exposure to alkali, as shown by experiments with solutions of trypsin and erepsin and with the specimens of contaminated gastric secretions from patients with pernicious anemia, failed in most instances to reduce the amino-nitrogen production to less than 2 mgm. within 24 hours. This technique cannot therefore be used to eliminate the production of total filtrable nitrogen by such interfering enzymes when present in any considerable concentration.

Because of this difficulty, the characteristics of only the two samples of gastric secretion from pernicious anemia patients which were visibly

\footnotetext{
4 Erepsin, Duodenal Digestive Ferment Company, Detroit, Michigan.
}

free from bile (experiments 408 and 415) may be justifiably compared with previous results on normal gastric juice. After exposure to alkali, there was, in both, minimal production of aminonitrogen but considerable ability to produce total filtrable nitrogen. Exposure to alkali in experiment $415 \mathrm{~b}$ did not affect the production of total filtrable nitrogen. Accordingly, this sample resembles normal gastric secretion; and because the amount of secretion, $78 \mathrm{ml}$. in an hour, was unusually great for the average patient with pernicious anemia (see Table IV), it is possible that the gastric secretion of this particular patient contained a greater amount of the enzyme in question than is usually contained in the gastric secretion of the typical pernicious anemia patient. With regard to the samples as a group, even in the six in which exposure to alkali reduced the formation of amino-nitrogen to less than $2 \mathrm{mgm}$. in 24 hours, the production of total filtrable nitrogen was not distinguishably less than for normal gastric juice (2).

Although we attempt to draw no conclusions from the data as a whole, because of the obvious experimental difficulties, it may not be out of place to discuss certain possible clinical difficulties in interpretation. Even if it is assumed that the in vitro activity of normal human gastric juice under discussion is identical with that of the socalled intrinsic factor, it is not necessary to suppose that the absence of such activity will always be characteristic of or can invariably serve as a diagnostic test for pernicious anemia. It has been demonstrated that certain amounts of extrinsic factor (200 grams of beef muscle) are usually unable to cause significant blood production when administered daily in pernicious anemia (10). When, however, presumably larger amounts $(7,11)$ of extrinsic factor (yeast preparations) are given, certain patients at least display hematopoietic responses, probably because of residual amounts of intrinsic factor in the gastric secretion. Because of the relatively insignificant volume of true gastric secretion in pernicious anemia, the development of the disease is perhaps not incompatible with a significant concentration of intrinsic factor in the gastric juice of certain patients. Thus Goldhamer (12) has 
demonstrated that when $150 \mathrm{ml}$. of gastric contents derived from pernicious anemia patients were given daily with 200 grams of beef muscle, moderate effects on blood production in another patient with pernicious anemia were observed. Accordingly, in explaining the development of any one case of macrocytic anemia responsive to treatment with liver extract, account must be taken not only of variations in the amount of intrinsic factor but also in the amount of extrinsic factor ingested $(4,13,14)$, of difficulty with intestinal absorption $(4,15)$, and possibly of positive or toxic factors of intestinal origin (16, 17). For this reason, any test applied to gastric secretion alone cannot be expected to be of absolute diagnostic significance.

If, however, the activity of normal human gastric juice described by Lasch (8) and ourselves $(1,2)$ is in reality a measure of the concentration of the so-called intrinsic factor, a satisfactory method for its quantification would still be of interest. Jones and Wilkinson (18) state that with the method of Lasch they have been unable to detect differences between normal and pernicious anemia gastric juice. In any case, because intestinal contents are usually present in samples of the gastric juice of patients with pernicious anemia, a satisfactory method of dealing with such material must distinguish the specific enzyme activity under investigation from that of enzymes regurgitated from the intestine.

\section{CONCLUSIONS}

1. Like the so-called intrinsic factor, the agent responsible for the proteolytic activity in vitro of normal human gastric juice at $\mathrm{pH} 7.4$ may be completely removed by adsorption with Lloyd's reagent. It is unable to penetrate a semipermeable membrane.

2. Because of the usual presence of interfering enzymes from the intestine, the in vitro method was unsatisfactory for determining in pernicious anemia the amount of proteolysis which could be ascribed to the proteolytic agent in normal human gastric juice referred to above.

\section{BIBLIOGRAPHY}

1. Taylor, F. H. L., Castle, W. B., Heinle, R. W., and Adams, M. A., Correlation of in vitro activity of normal human gastric juice on casein at $\mathrm{pH} 7.4$ with gastric intrinsic factor. Proc. Soc. Exper. Biol. and Med., 1937, 36, 566.

2. Taylor F. H. L., Castle, W. B., Heinle, R. W., and Adams, M. A., Observations on etiologic relationship of achylia gastrica to pernicious anemia. VII. Resemblances between proteolytic activity of normal human gastric juice on casein in neutral solution and activity of intrinsic factor. J. Clin. Invest., 1938, 17, 335.

3. Helmer, O. M., and Fouts, P. J., Fractionation studies on intrinsic factor in normal human gastric juice. Am. J. M. Sc., 1937, 194, 399.

4. Castle, W. B., and Ham, T. H., Observations on etiologic relationship of achylia gastrica to pernicious anemia. V. Further evidence for essential participation of extrinsic factor in hematopoietic responses to mixtures of beef muscle and gastric juice and to hog stomach mucosa. J. A. M. A., 1936, 107, 1456.

5. Helmer, O. M., Fouts, P. J., and Zerfas, L. G., Relationship of intrinsic factor to hematopoietic material in concentrated human gastric juice. Am. J. M. Sc., 1934, 188, 184.

6. Goldhamer, S. M., and Kyer, J., Chemical studies of intrinsic factor in desiccated stomach and normal human gastric juice. I. Separation of the intrinsic factor. Proc. Soc. Exper. Biol. and Med., 1938, 37, 659.

7. Wintrobe, M. M., Antianemic effect of yeast in pernicious anemia. Am. J. M. Sc., 1939, 197, 286.

8. Lasch, F., Uber eine biochemische Methode zur quantitativen Bestimmung des "intrinsic factor" nach Castle im Magensaft. Klin. Wchnschr., 1937, 16, 810.

9. Northrop, J. H., The inactivation of trypsin. III. Spontaneous inactivation. J. General Physiol., 1922, 4, 261.

10. Castle, W. B., Observations on etiologic relationship of achylia gastrica to pernicious anemia. I. Effect of administration to patients with pernicious anemia of contents of normal human stomach recovered after the ingestion of beef muscle. Am. J. M. Sc., 1929, 178, 748.

11. Ungley, C. C., Effect of yeast and wheat embryo in anaemias. I. Marmite, yestamin, and bemax in megalocytic and nutritional hypochromic anaemias. Quart. J. Med., 1933, 2, 381.

12. Goldhamer, S. M., Presence of intrinsic factor of Castle in gastric juice of patients with pernicious anemia. Am. J. M. Sc., 1936, 191, 405.

13. Groen, J., and Snapper, I., Dietary deficiency as cause of macrocytic anemia. Am. J. M. Sc., 1937, 193, 633. 
14. Elsom, K. O., Macrocytic anemia in pregnant women with vitamin B deficiency. J. Clin. Invest., 1937, 16, 463.

15. Groen, J., Absorption of glucose from small intestine in deficiency disease. New England J. Med., 1938, 218, 247.

16. Rhoads, C. P., and Miller, D. K., Induced susceptibility of blood to indol. J. Exper. Med., 1938, 67, 273.

17. Barker, W. H., and Hummel, L. E., Macrocytic ane- mia in association with intestinal strictures and anastomoses; review of the literature and report of two new cases. Bull. Johns Hopkins Hosp., 1939, 64, 215.

18. Jones T. S. G., and Wilkinson, J. F., Investigations on nature of haemopoietin, anti-anaemic principle in hog's stomach. IV. On biochemical method of Lasch for quantitative determination of " intrinsic factor" in gastric juice. Biochem. J., 1938, 32, 1352. 